\title{
Antidiuretic Activity of the Methanol Extract of Aporusa lindleyana Wight (Euphorbiacea) Baillon in Rats
}

\author{
Susantha K Ganegamage ${ }^{1}$, Thusitha U Abeytunga ${ }^{1}$ and Wanigasekara D \\ Ratnasooriya ${ }^{2 *}$ \\ ${ }^{1}$ Department of Chemistry, ${ }^{2}$ Department of Zoology, Faculty of Science, University of Colombo, PO Box 1490, Colombo, Sri \\ Lanka
}

*For correspondence: Email: wdr@zoology.cmb.ac.lk; Tel: +94112503399

Revised accepted: 7 April 2014

\begin{abstract}
Purpose: To determine the diuretic activity of Aporusa lindleyana in rats following its claimed use in Sri Lankan traditional medicine.

Methods: Three doses (500, 1000 and $1500 \mathrm{mg} / \mathrm{kg}$ ) of the methanol extract (ME) of Aporusa lindleyana (Leaf and bark in 5:1 ratio) were orally administered to female, adult Sprague Dawley rats. Furosemide, vasopressin (antidiuretic hormone) and distilled water were used as diuretic reference, antidiuretic reference and control, respectively. Urine output was recorded up to $6 \mathrm{~h}$ at hourly intervals. To investigate the mode of action, $\mathrm{pH}$, specific gravity, conductivity, total dissolve solids, $\mathrm{Na}^{+}, \mathrm{K}^{+}, \mathrm{Ca}^{2+}$, $\mathrm{Mg}^{2+}$, leucocytes, nitrite, urobilinogen, protein, blood, ketones, bilirubin and glucose were tested in the urine of $500 \mathrm{mg} / \mathrm{kg}$ treated and control rats. Six hours later, serum electrolyte levels $\left(\mathrm{Na}^{+}, \mathrm{K}^{+}, \mathrm{Ca}^{2+}\right.$ and $\mathrm{Mg}^{2+}$ ) were evaluated. Glomerular filtration rate (GFR) was also determined in terms of creatinine clearance. Overt toxicity, hepatotoxicity, nephrotoxicity and a phytochemical studies were conducted.

Results: Significant $(p<0.05)$ reduction of urine output (by $45 \%$ ) and aldosterone secretion index $\left(\mathrm{Na}^{+} / \mathrm{K}^{+}\right)$were observed while sodium (by $38 \%$ ) and potassium (by $114 \%$ ) levels were increased significantly $(p<0.05)$. GFR was not changed significantly $(p>0.05)$. Further, the methanol extract (leaf/bark in 5:1 ratio) was non-toxic in terms of overt signs of toxicity, serum alanine transaminase $(A L T)$ and aspartate aminotransferase (AST), urea and creatinine levels. Phytochemical evaluation revealed the presence of alkaloids, unsaturated sterols, unsaturated terpenes, unsaturated lactones, lucocyanins, tannins and polyphenols and cyanogenic glycosides.

Conclusion: The methanol extract of Aporusa lindleyana has moderate and safe oral antidiuretic activity.
\end{abstract}

Keywords: Aporusa lindleyana, Antidiuretic, Diuretic, Toxicity, Phytochemicals, Sri Lankan traditional medicine.

Tropical Journal of Pharmaceutical Research is indexed by Science Citation Index (SciSearch), Scopus, International Pharmaceutical Abstract, Chemical Abstracts, Embase, Index Copernicus, EBSCO, African Index Medicus, JournalSeek, Journal Citation Reports/Science Edition, Directory of Open Access Journals (DOAJ), African Journal Online, Bioline International, Open-J-Gate and Pharmacy Abstracts

\section{INTRODUCTION}

Sri Lanka has an enormous diversity of medicinal plants. Therapeutic value or biodynamic activities of many medicinal plants have still not been proven scientifically. Aporusa lindleyana (Wight) Bali (Family: Euphorbiacea), (Kebella or Barawa-
Embilla in Sinhala and Vittil, Kodali, Vettikan or Vitti in Tamil) is a medicinal plant, distributed in Sri Lanka and South India [1,2]. In Sri Lanka, it is preferably grown in intermediate zone areas and secondary forest and river banks. It is an evergreen tree up to $18 \mathrm{~m}$ tall, having branched brown coloured smooth stem. Leaves are 
deciduous, ovate-lanceolate in shape with undulate margins; leaf tip is acute and rounded to obtuse at the base [1,2]. In Sri Lankan traditional medicine, diuretic activity of $A$. lindleyana has been claimed as a main medicinal activity [1]. But its diuretic activity has not been scientifically proven. Other medicinal activities of this plant have been reported to possesses haemostasis, reddened/watery eyes, detoxifier for glory lily poisoning and as a blood purifying drug $[1,3]$. Also this plant has been used for several folk medicinal recipes in treatment of eye diseases, loose motions, cataract, diabetes, all types of anaemia in man and constipation in cows $[1,3]$.

Scientific studies have proven that pet ether, chloroform, methanol and water extracts of this plant has moderate to very good antibacterial activity (against Bacillus subtilus, Escherichia coli, Staphylococcus aureus and Klebsiella pneumonia), compared with the standard drug tetracycline as well as antifungi activity (against Pencilleum chrysozenous, Candida albicans, Aspergilus niger and Trichoderma vridar), compared with the standard drug fluconazole [4]. All the foregoing extracts of the bark have moderate analgesic activity on Swiss albino male mice [4]. The aqueous and alcoholic extracts of A. lindleyana possess anti-diabetic activity on alloxan-induced diabetic rats [5]. Ethanolic extract of the root of the plant has shown antiviral activities by in vitro HBsAg binding, HBV-DNA polymerase inhibition, RT (non-isotopic) inhibition and HSV inhibition [6]. Decoction of $A$. lindleyana roots is rich in antioxidants, phenolics and flavonoids. GC-MS studies also has proven that it has many phytochemicals such as squalene, phthalic acid and 1,2 benzene dicarboxylic acid, butyl cyclohexyl ester, etc [7]. The in vitro cytotoxicity studies against normal vero cell lines indicate non-toxic nature of ethanolic of extract of A. lindleyana root [7].

The aim of this study was to investigate the validity among Sri Lankan traditional practitioners that $A$. lindleyana has diuretic potential using the methanol extract. Methanol extract of plants are widely used and effective in determination of biodynamic activities such as diuretic/antidiuretic activities and phytochemical evaluations $[9,10]$.

\section{EXPERIMENTAL}

Plant materials were collected from Pinnaduwa Medicinal Plant Garden (6 $6^{\circ} 4^{\prime} 13^{\prime \prime} \mathrm{N}, 80^{\circ} 16^{\prime}$ $1.21 " \mathrm{E}$, elevation about 84 meters), Department Ayurveda, during September - November, 2011 at day time (between 10.00-13.00 h). The plant materials were identified and authenticated by Dr. HS Kathriarachchi at Department of Plant Science, University of Colombo. A voucher specimen (no. SKG/EU/001) was deposited at the museum of the Department of Botany, University of Colombo.

\section{Preparation of extract}

Plant materials were washed using running tap water. Then, plant parts were kept, under shade at room temperature $\left(30-32^{\circ} \mathrm{C}\right)$ until a constant weight (about 14 - 21 days) was obtained. Leaves and bark of shade-dried plant materials were crushed separately, using mechanical grinder (Blender FMI, Waring, New Jersey, USA). Grounded plant materials were homogenized in size using sieving. The plant materials $(900 \mathrm{~g})$, leaves and bark (5:1 ratio) were defatted by maceration process with petroleum ether ( $6 \mathrm{~L})$ for 7 days with occasional shaking. Defatted plant materials were extracted into methanol by refluxing on a water bath (Buchi Water bath, B-481, Buchi Labortechnik, Switzerland) at $65^{\circ} \mathrm{C}$ for $18 \mathrm{~h}$ (300 g on each occasion with $2 \mathrm{~L}$ for $6 \mathrm{~h} \times 3$ times).

Refluxed methanol portion was concentrated using rotary evaporator (EYELA, SB-650, Tokyo Rikakikai Co. Ltd, Japan) at $40{ }^{\circ} \mathrm{C}$. Final semisolid residue was freeze dried using freezedrying machine (Labconco, Labconco Corporation, USA) at $-58{ }^{\circ} \mathrm{C}$ to obtain a completely dry solid (79.98 g, $8.89 \%)$ and weighed (Libror, EB-3200D, Shimadzu Corporation, Japan). The crude, methanol extract (ME) was stored in airtight containers at $-20{ }^{\circ} \mathrm{C}$ until it is used. Well formulated homogeneous water suspension was prepared with this crude extract daily, 5 - 10 min before use.

\section{Experimental animals}

Healthy adult Sprague Dawley female rats (weight: 180 - $250 \mathrm{~g}$ ) were used in the study. The animals were kept in plastic cages (six per cage) in an animal house under standard animal house conditions (temperature: 28 - $32^{\circ} \mathrm{C}$, photoperiod: approximately $12 \mathrm{~h}$ natural light per day, relative humidity: 50 - $55 \%$ ). The animals were free to accesses pelleted food (Master Feeds Ltd, Colombo, Sri Lanka) and clear drinking water. Except at the time of the experimental procedure, the animals were handled only during cage cleaning. All the experiments were conducted in accordance with internationally accepted laboratory animal use and care guidelines $[8,11,12]$ and obtained clearance (EC/11/188) from Ethics Review Committee of Faculty of 
Medicine, University of Colombo, for animal experimentation.

\section{Drugs and chemicals}

Methanol (BDH Chemicals Ltd, Poole, England) was used as extracting solvent. Furosemide (State Pharmaceutical Manufacturing Company, Ratmalana, Sri Lanka) was used as diuretic reference and at the given dose of $13 \mathrm{mg} / \mathrm{kg}$ [11]. An antidiuretic hormone (vasopressin, Vasopin $₫$, Samarth Pharama Pvt. Ltd, Mumbai, India) was used as antidiuretic reference at a dose of 0.13 $\mathrm{ml} / \mathrm{rat}$. All the other chemicals used for phytochemical analysis were purchased from BDH Chemicals Ltd, Poole, England.

\section{Evaluation of diuretic/antidiuretic activity}

Forty nine rats were deprived of water for $18 \mathrm{~h}$. The rats were then orally administered with 15 $\mathrm{mL}$ of saline $(\mathrm{NaCl}, 0.9 \% \mathrm{w} / \mathrm{v})$ to impose uniform water load [9]. After $45 \mathrm{~min}$, urinary bladder of each rat was emptied by gentle compression of the pelvic area and by pulling of the tail. The rats were then randomly divided into six groups (assigned group numbers, I - VI) and treated either orally (Group-II-VI) or intraperitoneally (Group-I) according to the following manner, Group-I $(\mathrm{n}=6) 0.13 \mathrm{ml} / \mathrm{rat}$ antidiuretic hormone (ADH), Group-II ( $\mathrm{n}=6) 13 \mathrm{mg} / \mathrm{kg}$ furosemide, Group-III ( $\mathrm{n}=6) 500 \mathrm{mg} / \mathrm{kg} \mathrm{ME}$, Group-IV ( $=5)$ $1000 \mathrm{mg} / \mathrm{kg} \mathrm{ME}$, Group-V (n= 5) $1500 \mathrm{mg} / \mathrm{kg}$ ME, Group-VI $(n=21) 2 \mathrm{~mL}$ distilled water according to accepted laboratory handling techniques for rats [8]. Urine output was measured hourly over $6 \mathrm{~h}$ from the point of administration of saline to the rats.

Diuretic/antidiuretic activity was determined as the ratio of urinary output of treated to control group; diuretic potency as ratio of urinary out of treated to reference group; urinary excretion as the ratio of total urinary output to total volume of liquid administered; saline excreted as the ratio of urine volume excreted to volume of saline loaded; and change in urine output as the ratio of increased/decreased urine volume to urinary output of control group. All the foregoing parameters were expressed as a percentage [11].

\section{Evaluation of mechanism of action}

The collected urine for the $500 \mathrm{mg} / \mathrm{kg}$ dose was tested for leucosites, nitrite, urobilogen, protein, $\mathrm{pH}$, blood, specific gravity, ketone, bilirubine and glucose using urine test kit (Cortez Diagnostics. Inc, USA). Electrolytes such as $\mathrm{Na}^{+}, \mathrm{K}^{+}, \mathrm{Mg}^{2+}$ and $\mathrm{Ca}^{2+}$ ions concentration were measured (in ppm) using atomic absorption spectrophotometer (FAAS, GBC 935 plus, GBC Scientific Equipment Pty. Ltd, Victoria, Australia). Conductivity and total dissolve solids (TDS) were measured using conductivity meter (Jenway, 4510, Bibby Scientific Ltd, UK). The $\mathrm{pH}$ was measured using pH meter (Eutech, pH 510, Eutech Instruments, Singapore). Diuretic indices; sodium saliuretic index $\left(=\mathrm{Na}^{+}\right.$ion in treated group $/ \mathrm{Na}^{+}$ion in control group), potassium saliuretic index and aldosterone secretion index $\left(\mathrm{Na}^{+} / \mathrm{K}^{+}\right)$were calculated for $500 \mathrm{mg} / \mathrm{kg}$ dose of ME [11]. After 6 hrs administration of $500 \mathrm{mg} / \mathrm{kg}$ of ME, blood was withdrawn from tail and tested for selected electrolytes $\left(\mathrm{Na}^{+}, \mathrm{K}^{+}, \mathrm{Mg}^{2+}\right.$ and $\left.\mathrm{Ca}^{2+}\right)$ using atomic absorption spectrophotometer (FAAS, GBC 935 plus, GBC Scientific Equipment Pty. Ltd, Victoria, Australia) to check for any alteration of main electrolyte ions in serum.

\section{Estimation of creatinine clearance $\left(\mathrm{C}_{\mathrm{cr}}\right)$}

Ten $(n=10)$ rats were deprived of water for $18 \mathrm{~h}$ and orally administered with $15 \mathrm{~mL}$ of saline $(\mathrm{NaCl}, 0.9 \% \mathrm{w} / \mathrm{v})$ to impose a uniform water load. After $45 \mathrm{~min}$, urinary bladder of each rat was emptied by gentle compression of the pelvic area and by pulling of the tail. Then, rats were randomly divided into two groups $(n=5$ per group). First group was treated orally with 500 $\mathrm{mg} / \mathrm{kg}$ of ME and other group was given distilled water $(2 \mathrm{ml})$ orally. All rats were individually placed in metabolic cages. From the point of rat administration of saline, total urine output was measured, and thereafter, blood was drawn via the tail $24 \mathrm{~h}$ later [8]. Blood serum was separated and tested for creatinine using Randox creatinine kit (Randox Laboratories Ltd, UK) colourimetrically (UV -Visible Spectrophotometer, Jasco, V-560, Tokyo, Japan). Glomerular filtration rate (GFR) is measured in terms of $C_{c r}$ using creatinine in blood $\left(P_{c r}\right)$ and urine $\left(U_{c r}\right)$ and urine flow rate $\left(V_{t}\right)$, GFR $=\left(U_{c r} \times V_{t}\right) / P_{c r}[13]$.

\section{Evaluation of acute and subchronic toxicity}

Twelve rats $(n=12$, weighing $190-250 \mathrm{~g})$ were randomly divided into two groups ( $\mathrm{n}=6$ each). Distilled water $(2 \mathrm{ml} / \mathrm{rat})$ was orally given into group which served as the control group. Treated group were orally treated with the highest dose of the extract $(1500 \mathrm{mg} / \mathrm{kg})$ for 30 consecutive days. During this period, each rat for both the extract and the control group was observed for the following overt toxicity signs; salivation, lacrimation, breathing distress, ptosis, stupor, squint, teeth exposure, writhing, convulsions, tremors, yellowing of fur and loss of fur, stress (erection of fur and exophthalmia), behavioral abnormalities (biting and scratching, licking of 
tail, paw) and diarrohea. This observation was done daily $[9,11]$. On the 31 st day (one day posttreatment) rats from all the groups were anaesthetized with diethyl ether and blood was withdrawn from the tail under aseptic conditions $[8,11]$. Blood samples were kept at room temperature $\left(30{ }^{\circ} \mathrm{C}\right)$ for $1 \mathrm{~h}$, stored at $4{ }^{\circ} \mathrm{C}$ overnight and centrifuged at $4000 \mathrm{rpm}$ for 20 min. Serum layer was separated and tested for alanine transaminase (ALT), aspartate transaminase (AST), urea and creatinine levels colourimetrically (UV-Visible Spectrophotometer, Jasco, V-560, Tokyo, Japan) using respective Randox test kits (Randox Laboratories Ltd, London, UK) as per instructions given.

\section{Phytochemical screening}

The methanol extract of $A$. lindleyana plant (leaves and bark in 5:1 ratio) was subjected to qualitative determination of alkaloid, flavonoids, phenols, coumarines steroids, saponins, tannins, amino acids and peptides as described by Fong's phytochemical methods [14].

\section{Statistical analysis}

The data are expressed as mean \pm SEM. Statistical analysis was performed using MannWhitney U-test by Minitab 14.1 computer package. Significant level was set at $p<0.05$. Linear regression analysis was performed to assess dose dependencies.

\section{RESULTS}

Urine volumes in the rats administered with 500 $\mathrm{mg} / \mathrm{kg}$ of ME dose and ADH (0.13/rat) decreased significantly $(p=0.0318$ and 0.0047 , respectively). However, there was no significant $(p>0.05)$ difference of urine output of 1000 $\mathrm{mg} / \mathrm{kg}$ and $1500 \mathrm{mg} / \mathrm{kg}$ doses compared to the control group ( $p=0.1184,0.6488$ respectively) (see Table 1). The urine output decreased with the decreasing doses of ME. The antidiuretic activity of ME was inversely dose-dependent $\left(r^{2}\right.$ $=-98.6)$.

Table 1: Effect of oral administration of methanol extract (ME) of Aporusa lindleyana on urine output of rats

\begin{tabular}{|c|c|c|c|c|c|c|}
\hline \multirow[t]{2}{*}{ Treatment } & \multirow[t]{2}{*}{$\begin{array}{l}\text { Total urine } \\
\text { output (ml) }\end{array}$} & \multirow[t]{2}{*}{$\begin{array}{l}\text { Change of urine } \\
\text { volume ( } \%)\end{array}$} & \multicolumn{2}{|c|}{$\begin{array}{l}\text { Diureticl } \\
\text { antidiuretic }\end{array}$} & \multirow[t]{2}{*}{$\begin{array}{l}\% \text { Saline } \\
\text { excreted }\end{array}$} & \multirow[t]{2}{*}{$\begin{array}{l}\% \text { Urinary } \\
\text { excretion }\end{array}$} \\
\hline & & & & Potency & & \\
\hline Furosemide, $13 \mathrm{mg} / \mathrm{kg}$ & $1.98 \pm 0.20^{*}$ & Ic $57 \%$ & 1.57 & 1.00 & $13.22 \pm 1.35^{\star}$ & 11.66 $1.19^{*}$ \\
\hline $\mathrm{ME}, 500 \mathrm{mg} / \mathrm{kg}$ & $0.70 \pm 0.08^{*}$ & Dc $45 \%$ & 1.80 & 0.71 & $4.66 \pm 0.54^{*}$ & $4.11 \pm 0.48^{*}$ \\
\hline $\mathrm{ME}, 1000 \mathrm{mg} / \mathrm{kg}$ & $0.87 \pm 0.08$ & Dc $31 \%$ & 1.44 & 0.57 & $5.84 \pm 0.49$ & $5.15 \pm 0.44$ \\
\hline ME, 1500 mg/kg & $1.09 \pm 0.15$ & Dc $11 \%$ & 1.12 & 0.44 & $7.48 \pm 1.00$ & $6.60 \pm 0.88$ \\
\hline $\mathrm{ADH}, 0.13 \mathrm{ml} / \mathrm{rat}$, & $0.50 \pm 0.03^{*}$ & Dc $60 \%$ & 2.53 & 1.00 & $3.33 \pm 0.23^{*}$ & $2.93 \pm 0.20^{*}$ \\
\hline $\mathrm{DW}, 2 \mathrm{~mL}$ & $1.26 \pm 0.12$ & - & - & - & $8.41 \pm 0.78$ & $7.42 \pm 0.69$ \\
\hline
\end{tabular}

${ }^{*} p<0.05$, compared to control by non-parametric test (Mann Whitney U-test); $n=5,6$ (or 21 for the control group that received distilled water, DW); \% change in urine volume was done in comparison with the control group; Ic = increase; $D c=$ decrease

Table 2: Effect of oral administration of the methanol extract (ME) of Aporusa lindleyana (500 mg/kg) on some urine parameters (up to $6 \mathrm{~h}$ ) on rats

\begin{tabular}{|c|c|c|}
\hline Parameter & Control group & $500 \mathrm{mg} / \mathrm{kg}$ extract \\
\hline $\mathrm{pH}$ & $6.41 \pm 0.29$ & $6.53 \pm 0.04$ \\
\hline Specific Gravity (SG) & $1.025 \pm 0.0016$ & $1.026 \pm 0.0015$ \\
\hline Conductivity / $\mu \mathrm{S}$ & $17.72 \pm 2.37$ & $25.79 \pm 3.76$ \\
\hline Total Dissolve Solids (TDS) $/ \mathrm{mgL}^{-1}$ & $9.75 \pm 1.76$ & $12.86 \pm 1.02$ \\
\hline $\mathrm{Na}^{+}(\mathrm{ppm})$ & $5346.67 \pm 564.19$ & $7373.33 \pm 612.07^{*}$ \\
\hline $\mathrm{K}^{+}(\mathrm{ppm})$ & $2614.00 \pm 321.30$ & $5581.50 \pm 697.13^{*}$ \\
\hline $\mathrm{Ca}^{2+}(\mathrm{ppm})$ & $387.20 \pm 30.58$ & $216.66 \pm 88.32$ \\
\hline $\mathrm{Mg}^{2+}(\mathrm{ppm})$ & $631.00 \pm 78.95$ & $791.67 \pm 75.82$ \\
\hline Sodium Saliuretic Index & 1.0 & 1.38 \\
\hline Potassium Saliuretic Index & 1.0 & 2.14 \\
\hline Aldesterone Secretion Index $\left(\mathrm{Na}^{+} / \mathrm{K}^{+}\right)$ & $2.11 \pm 0.19$ & $1.40 \pm 0.14^{*}$ \\
\hline Leucosites (cells/ $\mu \mathrm{L})$ & N.D & N.D \\
\hline Nitrite (in terms of organisms $/ \mathrm{ml}$ ) & N.D & N.D \\
\hline Urobilogen $(\mu \mathrm{mol} / \mathrm{L})$ & N.D & N.D \\
\hline Protein (mg/dL) & N.D & N.D \\
\hline Blood (cells $/ \mu \mathrm{L}$ ) & N.D & N.D \\
\hline Ketone (mg/dL) & N.D & N.D \\
\hline Bilirubine $(+/-)$ & N.D & N.D \\
\hline Glucose (mg/dL) & N.D & N.D \\
\hline
\end{tabular}


As shown in Table 2, $500 \mathrm{mg} / \mathrm{kg}$ of $\mathrm{ME}$ did not significantly $(p<0.05)$ alter the $\mathrm{pH}$, SG, conductivity and TDS compared to the control group $(p=0.1282,0.8312,0.0927$ and 0.2298 respectively). On the other hand, sodium (by 38 $\%$ ) and potassium (by $114 \%$ ) levels significantly $(p<0.05)$ increased compared to control group $(p=0.0453,0.0131$ and respectively) and $\mathrm{Na}+/ \mathrm{K}+$ ratio was significantly $(p<0.05)$ decreased $(p=0.0131)$ compared to control group (see Table 2). Any abnormality of urine (in terms of leucosites, nitrite, urobilogen, protein, blood, ketone, bilirubine and glucose) was not detected.

Further, significant alteration $(p>0.05)$ of creatinine clearance was not observed in test group $(4.61 \pm 1.62 \mathrm{ml} / \mathrm{h})$ compared to control group $(6.83 \pm 2.15 \mathrm{ml} / \mathrm{h})(p=0.5309)$.

Table 3: The effect of 30 days oral administration of methanolic extract (ME) of Aporusa lindleyana (1500 $\mathrm{mg} / \mathrm{kg}$ ) on some serum parameters on rats Mean \pm SEM)

\begin{tabular}{lll}
\hline Parameter & Test Group & Control Group \\
\hline Urea $(\mathrm{mg} / \mathrm{dL})$ & $33.60 \pm 2.981$ & $34.82 \pm 2.398$ \\
Creatinine $(\mathrm{mg} / \mathrm{dL})$ & $1.20 \pm 0.067$ & $0.99 \pm 0.141$ \\
ALT $(\mathrm{U} / \mathrm{l})$ & $69.84 \pm 7.557$ & $59.36 \pm 14.968$ \\
AST $(\mathrm{U} / \mathrm{l})$ & $127.75 \pm 22.055$ & $139.10 \pm 69.173$ \\
\hline
\end{tabular}

In the toxicity study, $1500 \mathrm{mg} / \mathrm{kg}$ dose of ME did not provoke any overt sings of toxicity, stress, behavioural abnormalities, aversive behaviour or diarrhoea. In addition, none of the treated rats died. After feeding for 30 consecutive days (see Table 3), none of investigated serum parameters (urea, creatinine, ALT and AST levels) were significantly $(p<0.05)$ altered $(p=1.0000$, $0.4386,0.6985$ and 0.5186 respectively).

\section{Phytochemical profile of extract}

Alkaloid test showed presence of primary, secondary or tertiary alkaloids but absence of quaternary alkaloids or amine oxides. Lieberman-Burchard test and the Salkowski test indicated the presence of unsaturated sterols and triterpenes. Unsaturated lactones and 2deoxy sugar test gave positive results. Flavonoids and leucoanthocyanin screening results showed absence of cyanidin but presence of leucocyanins and flavonoids. Borntrager test and modified Bornteager test gave negative results due to the absence of anthroquinones. A positive result for picrate paper test indicates the presence of cyanogenic glycosides. Froth test gave negative results for saponins.

\section{DISCUSSION}

This study examined the effect of methanolic extract of $A$. lindleyana (ME) on urine output of rats. The results showed that ME has moderate antidiuretic activity (in terms of antidiuretic action, antidiuretic activity, percentage of urinary excretion, percentage saline excreted, percentage change of urine output and aldosterone secretion index compared to control group). This does not support the claim made by Sri Lankan traditional medicine that it is a potent oral diuretic. It is an important finding with therapeutic implications because about $35 \%$ of Sri Lankan population still mainly depends on Ayurvedic and Sri Lankan traditional medicines for primary healthcare [15].

The lowest dose of the extract $(500 \mathrm{mg} / \mathrm{kg}$ ) showed the highest antidiuretic activity while highest dose demonstrated the lowest antidiuretic activity, thus indicating an inverse dose-relationship. It significantly decreased urine output (by $45 \%$ ) compared to control group. The urine of rat treated with the lowest dose of ME was markedly hypernatremic (in terms of urinary $\mathrm{Na}^{+}$level and sodium saliuretic index) and hyperkalemic (in terms of urinary $\mathrm{K}^{+}$level and potassium saliuretic index). Urinary sodium and potassium levels were significantly increased. Aldosterone secretion index $\left(\mathrm{Na}^{+} / \mathrm{K}^{+}\right)$decreased significantly. GFR (in terms of creatinine clearance) indicated that ME did not alter ultrafiltration process and clearly the dose not act on glomerulus of nephron.

The antidiuretic action of a herbal drug may be mediated by several methods $[15,16]$. Some antidiuretics impair GFR [17]. The ME of $A$. lindleyana did not decrease the GFR of treated rats. Therefore, antidiuretic activity of ME is unlikely to be mediate via this mechanism. An antidiuretic action can be mediated by increasing the $A D H$ secretion from posterior pituitary and/or by having agonist activity to the $A D H V 2$ receptor present in the distal convoluted tubule and collecting duct of nephrons, which would enhance water reabsorption possibly increasing urinary sodium and potassium level as evident in this study [13].

Antidiuretic effects in the human body are brought about by $\mathrm{ADH}$ and aldosterone [13]. Both hormones help to retain water but the mechanism by which it reabsorbs the water is different. It is claimed that ADH has the ability to reabsorb urea and it helps to reabsorb water along with it. In contrast, aldosterone reabsorbs 
sodium and this helps in the reabsorption of water. As such, these two modes of action may be possible for the antidiuretic action of ME of $A$. lindleyana. Alternatively, increased secretion of aldosterone from adrenal cortex and/or agonist activity to aldosterone can induce antidiuresis. Such a mode of action is also possible since there was a significant reduction in aldosterone index $\left(\mathrm{Na}^{+} / \mathrm{K}^{+}\right.$ratio) and significant increase in urinary potassium level. Thus, the antidiuretic action of ME is likely to be mediated by $\mathrm{ADH}$ and aldosterone mechanisms.

It is reported that the alkaloids, dioscorine and dioscine, can produce antidiuretic effect [18]. Some steroid-derived alkaloids found in plants (veratridine) can inhibit water diuresis in unanaesthetized rats [19]. Among these secondary metabolites, it has been reported that some flavonoids (namely chrysin, oroxylin-A, baicalein, biochanin-A,and ellagic acid) possess the antiinflammatory, antidiuretic, anti arthritic, antimicrobial activities [20]. It is known that some plant (Rubia tinctorium L) anthraquinone derivates have been used as anti-diuretic drugs [21]. One or few of these compounds can be present in the methanol extract of $A$. lindleyana plant (ME). Combination of action of this plant secondary metabolites may have produced this antidiuretic effect.

Toxicity studies showed that ME (up to 1500 $\mathrm{mg} / \mathrm{kg}$ ) is well tolerated (in terms of overt signs of toxicity), and did not produce any renotoxicity (in terms of serum urea, creatinine, leucosites, nitrite, urobilogen, protein, $\mathrm{pH}$, blood, specific gravity, ketone, bilirubine and glucose) and hepatotoxicity (in terms of serum ALT and AST). Furthermore, no mortality was evident during the toxicity studies. These observations suggest that ME of $A$. lindleyana may be safe for regular consumption.

\section{CONCLUSION}

The methanol extract of $A$. lindleyana has moderate and safe oral antidiuretic activity. This may be useful in the management of polyuria.

\section{ACKNOWLEDGEMENT}

Technical support given by Mr TRK Perera (Animal House, Faculty of Medicine, University of Colombo, Sri Lanka.) and Mr K Ariyasena (Department of Chemistry, Faculty of Science, University of Colombo, Sri Lanka.) is greatly acknowledged.

\section{REFERENCES}

1. Ramanayake L, De Silva G, Perera DL, Ponnamperuma A, A Sri Lankan study of compendium of medicinal plants Vol. 04. Sri Lanka: Department Of Ayurveda; 2004; pp 30-33.

2. Dasanayake $M D$, Clayton $W D$, editors. A revised handbook to the flora of Ceylon Vol. 11. 1997. p. 270271.

3. Weragoda PB, editor. Osuthuru Visithuru, Vol. 02. Department of Ayurveda. Sri Lanka. 1994. p. 117121.

4. Lingadahalli PS, Hosadu MV, Basavanakote MB, Vijayavittala PV. Evaluation of antimicrobial and analgesic activities of Aporosa lindleyana (Euphorbiaceae) bark extract. Int J Green Pharm. 2008; 2: 155-157.

5. Jung $M$, Park M, Lee HC, Kang YH, Kang ES, Kim SK. Antidiabetic agents from medicinal plants. Curr Med Chem 2006; 13: 1203-1218.

6. Venkataraman R, Gopalakrishnan S, Thyagarajan SP. Antiviral activities of Aporosa lindleyana Baill. Ann Biol Res 2010; 1: 68-70.

7. Ramakrishnan S, Venkataraman $R$. Screening of antioxidant activity, total phenolics and gas chromatography-mass spectrophotometer (GC-MS) study of ethanolic extract of Aporosa lindleyana Baill. Afr J Biochem Res 2011; 5: 360-364.

8. Gay WI. Methods of animal experimentation (Vol-I). New York: Academic Press; 1965. p. 32-191.

9. Koriem KM, Arbid MS, Asaad GF. Chelidonium majus leaves methanol extract and its chelidonine alkaloid ingredient reduce cadmium-induced nephrotoxicity in rats. J Nat Med 2013; 67: 159-167.

10. Hemamalini K, Naik KOP, Ashok P. Study of Phytochemical and diuretic potential of methanol and aqueous extracts of leaf parts of Anogiessus Latifolia. Int J Res Pharm Biomed Sci 2011; 2: 136-139.

11. Abewickrama KRW, Ratnasooriya WD, Amarakoon AMT. Oral diuretic activity of hot water infusion of sri lankan black tea (Camellia sinensis L.) in rats. Phcog Mag 2010; 6: 271-277.

12. Garber JC, Barbee WR, Bielitzki JT, Clayton LA, Donovan JC, Kohn DF, Lipman NS, Locke P, Melcher J, Quimby FW, et al. Guide for the Care and Use of Laboratory Animals. New York: The National Academies Press; 2010; $p 213$.

13. Koeppen BM, Stantion BA. Renal Physiology. 4th ed. India: Reed Elesevir; 2007. p. 228.

14. Fong HHS, Maung TW, Fransworth NR. phytochemical screening, Chicago: Department of Pharmacognosy and Pharmacology, University of Illinols; 1973; $p 65$.

15. Ediriweera ERHSS, Ratnasooriya WD. Antidiuretic effect of Scoparia dulsis in rats, $J$ Tro Med Plants 2002; 3: 55-58.

16. Ratnasooriya WD, Jayakody JRAC, Nadarajah $T$. Antidiuretic activity of aqueous bark extract of Sri 
Lankan Ficus racemosa in rats, Acta Biol Hung 2003; 54: 357-363.

17. Anderson WP, Heguilen RM, Woods RL. Intrarenal infusions of endothelin in conscious dogs: interactions with prostanoids and angiotensin II. J Cardiovasc Pharmacol 1995; 26: 511-517.

18. Broadbent JL, Schnieden H. A comparison of some pharmacological properties of dioscorine and dioscine. Br J Pharmacol Chemother 1958; 13: 213215.
19. Chaudhri KUN. Renal effects of veratridine. $\mathrm{Br} \mathrm{J}$ Pharmacol 1959; 14: 74-82.

20. Choudhury S, Datta S, Talukdar AD, Choudhury MD. Phytochemistry of the Family Bignoniaceae- A review. Assam University J Sci Technol 2011; 7: 145150.

21. Gölcü A, Dolaz M, Digrak M, Serin S. The biological activity of dyer's madder (Rubia tinctorium L). Proc ICNP-Trabzon-Turkey 2002: 255-258. 